\title{
Digestate from Biogas Plants is an Attractive Alternative to Mineral Fertilisation of Kohlrabi
}

\author{
Tomas Losak ${ }^{* 1}$, Jaroslav Hlusek, Andrea Zatloukalova ${ }^{2}$, Ludmila Musilova ${ }^{2}$, Monika \\ Vitezova ${ }^{2}$, Petr Skarpa ${ }^{2}$, Tereza Zlamalova ${ }^{2}$, Jiri Fryc ${ }^{3}$, Tomas Vitez ${ }^{3}$, Jan Marecek ${ }^{3}$, \\ Anna Martensson ${ }^{4}$ \\ ${ }^{1}$ Department of Environmentalistics and Natural Resources, Faculty of Regional Development and \\ International Studies, Mendel University in Brno, Brno, Czech Republic \\ e-mail: losak@mendelu.cz \\ ${ }^{2}$ Department of Agrochemistry, Soil Science, Microbiology and Plant Nutrition, \\ Faculty of Agronomy, Mendel University in Brno, Brno, Czech Republic \\ ${ }^{3}$ Department of Agricultural, Food and Environmental Engineering, Faculty of \\ Agronomy, Mendel University in Brno, Brno, Czech Republic \\ ${ }^{4}$ Department of Soil and Environment, Swedish University of Agricultural Sciences, Uppsala, Sweden
} http://dx.doi.org/10.13044/j.sdewes.2014.02.0025

\begin{abstract}
This study examined the potential for the use of digestate from biogas plants for the fertilisation of kohlrabi. Kohlrabi was grown in two pot experiments in consecutive years using digestate, mineral fertiliser (urea) with a nitrogen $(\mathrm{N})$ content equivalent to that in the digestate, mineral fertiliser with $\mathrm{N}$, phosphate $(\mathrm{P})$, potassium $(\mathrm{K})$ and magnesium $(\mathrm{Mg})$ contents equivalent to the digestate, and an unfertilised control. At harvest, the soil receiving the digestate application had higher $\mathrm{P}, \mathrm{K}$ and $\mathrm{Mg}$ contents than the control and the urea treatment. The soil $\mathrm{N}_{\min }$ content was balanced in all fertilised treatments. Soil $\mathrm{pH}$ was unaffected by all treatments. Kohlrabi bulbs from the unfertilised control had the lowest weight, nitrate content and ascorbic acid content. Digestate and NPKMg fertiliser treatments increased bulb weight compared with the $\mathrm{N}$-only urea treatment. Ascorbic acid content did not differ between fertilised treatments. There were no differences in bulb nitrate content between the mineral fertiliser treatments, but digestate application gave a low nitrate content. Bulb macroelement contents varied irregularly among treatments.
\end{abstract}

\section{KEYWORDS}

Biogas plant, Digestate, Fertilisation, Soil, Kohlrabi, Yields, Quality.

\section{INTRODUCTION}

In recent years there has been a major expansion in the production and use of biogas in Europe for the co-generation of electricity and heat. For farmers, biogas stations (BGS) offer a new and predictable production of 'environmentally friendly' energy. However, the widespread production of biogas presents a number of new questions, including the subsequent use of the residue from anaerobic fermentation - digestate [1,2]. Field and pot trials to date report positive effects of digestate application to arable land in terms of yield [3-5] or no significant effects [6,7]. Experts are divided in their opinions on the properties and possibilities for the practical use of digestate as an organic fertiliser [8-10].

\footnotetext{
* Corresponding author
} 
Digestion is associated with large losses of organic carbon (C) [11]. During the digestion process, $24-80 \%$ of organic dry matter is transformed to methane $\left(\mathrm{CH}_{4}\right)$ and carbon dioxide $\left(\mathrm{CO}_{2}\right)$ [12]. However, the digestate produced is rich in $\mathrm{N}$ and has a high ammonium-N/total $\mathrm{N}$ ratio, making it potentially suitable as a fertiliser. Comparisons between digestate applications and mineral $\mathrm{N}$ fertilisers based on equivalent amounts of total $\mathrm{N}$ have shown lower fertiliser $\mathrm{N}$-values than the mineral $\mathrm{N}$ fertilisers [13]. Higher ammonia losses after spreading digested slurry were observed, because anaerobic digestion of manure increases the ammonium $\left(\mathrm{NH}_{4}{ }^{+}\right)$concentration as well as the $\mathrm{pH}$, and both these factors promote gaseous $\mathrm{N}$ loss [14]. Where anaerobic digestate has been applied in the field a significant negative correlation between net $\mathrm{N}$-mineralisation and mineralised-C has been reported in the soil [15]. The digestion of energy crops alone or in combination with animal manures leads to an additional quantity of organic manure [16].

Although current regulations define digestate as an organic fertiliser, its composition and properties are closer to that of compound mineral fertiliser. When fertilising with digestate it is therefore necessary to apply other sources of primary (labile) organic matter of good quality to the soil at the same time, e.g. by ploughing down all post-harvest residues, applying farm manure, compost, straw [1,9] or using a catch crop, e.g. clover-grass mixture.

The aim of this study was to evaluate the effect of digestate application on chemical soil properties, yield and chemical composition of kohlrabi.

\section{MATERIAL AND METHODS}

Two pot experiments were established on 8 June 2010 and on 21 May 2011. Mitscherlich plant pots were filled with $6 \mathrm{~kg}$ of medium heavy soil characterised as fluvial soil with the chemical properties as shown in Table 1.

Table 1. Chemical characteristics of soil prior to establishment of the experiments (Mehlich III)

\begin{tabular}{ccccc}
\hline \multirow{2}{*}{$\mathrm{pH} / \mathrm{CaCl}_{2}$} & \multicolumn{5}{c}{$\mathrm{mg} / \mathrm{kg}$} \\
\cline { 2 - 5 } & $\mathrm{P}$ & $\mathrm{K}$ & $\mathrm{Ca}$ & $\mathrm{Mg}$ \\
\hline 7.5 & 34 & 159 & 6,262 & 303 \\
Alkaline & Low & Satisfactory & Very high & Good \\
\hline
\end{tabular}

The experiments involved four treatments, as shown in Table 2. The digestate $(\mathrm{C} / \mathrm{N}$ ratio 4/1) was obtained from a biogas station which uses pig slurry and maize silage from hybrid KWS 1393 as its raw material inputs.

In addition a bio-enzymatic preparation (APD BIO GAS) was applied into the fermentor to increase biogas production. The preparation consists of a mixture of bacterial and enzymatic cultures and nutrients and is claimed to have a significant beneficial effect on the activity of the microorganisms involved in the process of methanogenesis. This results in an increase in biogas production, the elimination of odour due to a decrease in the volatilisation of ammonia, higher homogeneity of the substrate preventing the creation of a surface crust and sediments, and improved handling of the fermentation residue and its application to the land.

Tables 3 and 4 show the composition of the digestate in terms of content of nutrients and hazardous elements, respectively. The contents of all hazardous elements were below the limit specified in Regulation No. 271/2009 Coll. (Table 4).

Mineral fertilisers and digestate were applied by watering and were thoroughly mixed with the entire contents of the pot. Two seedlings of kohlrabi cv. Moravia were planted 
10 days after fertilisation. The pots were watered to $60 \%$ of maximum capillary capacity and were kept free of weeds. The bulbs were harvested at full maturity on 2 August 2010 in the first year and on 19 July 2011 in the second. Immediately after harvest the individual bulbs without leaves were weighed. Nitrate concentration ( $\left.\mathrm{mg} \mathrm{NO}{ }_{3}{ }^{-} / \mathrm{kg}^{2}\right)$ was determined in the fresh matter of bulbs with a potentiometer using an ion selective electrode (ISE). The ascorbic acid content was determined in fresh matter using the capillary isotachophoresis method.

The soil was extracted according to Mehlich III $\left(\mathrm{CH}_{3} \mathrm{COOH}, \mathrm{NH}_{4} \mathrm{NO}_{3}, \mathrm{NH}_{4} \mathrm{~F}, \mathrm{HNO}_{3}\right.$ and EDTA). The content of available $\mathrm{P}$ in the extract was determined colorimetrically and the content of available $\mathrm{K}, \mathrm{Mg}$ and $\mathrm{Ca}$ using an AAS. The ion-selective electrode (ISE) was used to determine the $\mathrm{pH}$ value [17]. The content of $\mathrm{N}^{-\mathrm{NH}_{4}}{ }^{+}$in the soil was assessed colorimetrically; the $\mathrm{N}_{-} \mathrm{NO}_{3}{ }^{-}$content using ISE. The content of macrobiogenic elements in the plant biomass was assessed after wet mineralisation $\left(\mathrm{H}_{2} \mathrm{SO}_{4}+\mathrm{H}_{2} \mathrm{O}_{2}\right)$. The $\mathrm{N}$ content was determined by Kjeldahl analysis, while colorimetric analysis was used to assess $\mathrm{P}$, and the AAS method to assess $\mathrm{K}, \mathrm{Ca}$ and $\mathrm{Mg}$ [18].

The results were processed statistically using variance analysis followed by testing according to Scheffe $(\mathrm{P}<0.05)$.

Table 2. Treatments used in the pot experiment

\begin{tabular}{cccc}
\hline $\begin{array}{c}\text { Treatment } \\
\text { No. }\end{array}$ & Description & $\begin{array}{c}\text { Dose of nutrients } \\
(\mathrm{g} / \mathrm{pot}): \\
\text { N-P-K-Mg }\end{array}$ & Fertiliser \\
\hline 1 & Untreated control & 0 & - \\
2 & N fertiliser & $1.5-0-0-0$ & Urea \\
3 & Digestate & $1.5-0.18-0.69-0.08$ & $\begin{array}{c}\text { Digestate } \\
4\end{array}$ \\
NPKMg fertiliser & $1.5-0.18-0.69-0.08$ & Urea, triple superphosphate, \\
KCl, $\mathrm{MgSO}_{4}$
\end{tabular}

Table 3. Contents of major plant nutrients in the digestate

\begin{tabular}{cccccc}
\hline \multirow{2}{*}{$\%$} & $\mathrm{~N}$ & $\mathrm{P}$ & $\mathrm{K}$ & $\mathrm{Ca}$ & $\mathrm{Mg}$ \\
\cline { 2 - 6 } & 11.4 & 1.37 & 5.2 & 2.02 & 0.62 \\
Of dry matter & 0.72 & 0.09 & 0.31 & 0.13 & 0.04 \\
\hline
\end{tabular}

Table 4. Contents of hazardous elements in the digestate and max. permissible levels

\begin{tabular}{cccccccccc}
\hline & \multicolumn{10}{c}{$\mathrm{mg} / \mathrm{kg}$ dry matter } \\
\cline { 2 - 10 } & $\mathrm{Cd}$ & $\mathrm{Pb}$ & $\mathrm{Hg}$ & $\mathrm{As}$ & $\mathrm{Cr}$ & $\mathrm{Cu}$ & $\mathrm{Mo}$ & $\mathrm{Ni}$ & $\mathrm{Zn}$ \\
\hline Content & 0.1 & 2.4 & 0.2 & 0.2 & 9.1 & 99 & 4.6 & 8.6 & 481 \\
max.* & 2 & 100 & 1 & 20 & 100 & 250 & 20 & 50 & 1200 \\
\hline
\end{tabular}

"maximum permissible level according to Regulation No. 271/2009 Coll.

\section{RESULTS AND DISCUSSION}

\section{Post-harvest changes in soil chemical properties}

Plant nutrients are present in inorganic plant-available forms to a markedly higher level in digested residue than in untreated waste [19], due to the mineralisation of large 
amounts of organically bound nutrients during the digestion process [20]. Table 5 shows the post-harvest values of some chemical characteristics of the soil $(\mathrm{pH}$, available $\mathrm{P}, \mathrm{K}$, $\mathrm{Ca}, \mathrm{Mg}$ ) following the different treatments.

Table 5. Post-harvest content of available nutrients and $\mathrm{pH}$ of the soil receiving the different treatments (2010 and 2011)

\begin{tabular}{|c|c|c|c|c|c|c|}
\hline \multirow{2}{*}{$\begin{array}{c}\text { Treat. } \\
\text { No. }\end{array}$} & \multirow{2}{*}{ Scheme } & \multirow{2}{*}{$\mathrm{pH} / \mathrm{CaCl}_{2}$} & \multicolumn{4}{|c|}{$\mathrm{mg} / \mathrm{kg}$} \\
\hline & & & $\mathrm{P}$ & K & $\mathrm{Ca}$ & $\mathrm{Mg}$ \\
\hline & & \multicolumn{5}{|c|}{ Year 2010} \\
\hline 1 & Control & $7.49^{\mathrm{a}}$ & $28^{\mathrm{a}}$ & $142^{\mathrm{a}}$ & $6,158^{\mathrm{a}}$ & $275^{\mathrm{a}}$ \\
\hline 2 & $\mathrm{~N}$ fertiliser & $7.48^{\mathrm{a}}$ & $25^{\mathrm{a}}$ & $138^{\mathrm{a}}$ & $6,153^{\mathrm{a}}$ & $271^{\mathrm{a}}$ \\
\hline 3 & Digestate & $7.49^{\mathrm{a}}$ & $48^{\mathrm{b}}$ & $162^{\mathrm{b}}$ & $6,117^{\mathrm{a}}$ & $302^{\mathrm{b}}$ \\
\hline \multirow[t]{2}{*}{4} & NPKMg fertiliser & $7.47^{\mathrm{a}}$ & $50^{\mathrm{b}}$ & $151^{\mathrm{b}}$ & $6,124^{\mathrm{a}}$ & $294^{\mathrm{b}}$ \\
\hline & & \multicolumn{5}{|c|}{ Year 2011} \\
\hline 1 & Control & $7.36^{\mathrm{a}}$ & $27^{\mathrm{a}}$ & $152^{\mathrm{a}}$ & $7,136^{\mathrm{a}}$ & $282^{\mathrm{a}}$ \\
\hline 2 & $\mathrm{~N}$ fertiliser & $7.35^{\mathrm{a}}$ & $26^{\mathrm{a}}$ & $145^{\mathrm{a}}$ & $7,093^{\mathrm{a}}$ & $288^{\mathrm{a}}$ \\
\hline 3 & Digestate & $7.37^{\mathrm{a}}$ & $46^{\mathrm{b}}$ & $171^{\mathrm{b}}$ & $7,191^{\mathrm{a}}$ & $343^{b}$ \\
\hline 4 & NPKMg fertiliser & $7.37^{\mathrm{a}}$ & $40^{\mathrm{b}}$ & $161^{\mathrm{b}}$ & $7,214^{\mathrm{a}}$ & $331^{\mathrm{b}}$ \\
\hline
\end{tabular}

Different letters $(a, b)$ within the columns indicate significant differences between treatments for each year extra $(\mathrm{P}<0.05)$

In the treatment with digestate and that with NPKMg fertiliser, the contents of $\mathrm{P}, \mathrm{K}$ and $\mathrm{Mg}$ in the soil were found to have increased significantly after harvest compared with the other treatments (Table 5). Thus the soil was enriched with these nutrients after application of these two fertilisers despite the removal of nutrients in the harvested kohlrabi. Both treatments also produced considerably higher yields of bulbs (and hence also higher nutrient uptake) than the other treatments. Loria and Sawyer [21] reported that anaerobically digested liquid swine manure could provide similar plant-available $\mathrm{N}$ and $\mathrm{P}$ as would be expected from raw swine manure. In the present study, there were no differences between treatments in terms of soil $\mathrm{pH}$ (Table 5). Digestate is alkaline and increases the soil $\mathrm{pH}$ [22] making it suitable for acid soils. The reason for the reduction in soil $\mathrm{K}$ content in the $\mathrm{N}$ fertiliser treatment was its higher uptake by plants as a result of the synergistic effect of $\mathrm{N}$ fertilisation [23].

Nitrogen is the nutrient most subject to transformations affecting its availability to plants. These transformations include mineralisation, immobilisation, nitrification and denitrification, as well as leaching and ammonia volatilisation [24]. It is difficult to synchronise the supply of $\mathrm{N}$ from organic manures with the demand by crops for $\mathrm{N}$ [25]. Soil microbial activity leads to $\mathrm{N}$ release that is not necessarily in synchrony with plant nutrient demand [26]. The elevated $\mathrm{NH}_{4}{ }^{+}-\mathrm{N}$ concentration in digested effluents suggests its potential suitability as a readily available $\mathrm{N}$ fertiliser source.

The post-harvest soil content of $\mathrm{N}_{\min }$ was lowest in the unfertilised treatment (Table 6). No appreciable differences in the total content of $\mathrm{N}_{\min }(6.12-7.57 \mathrm{mg} / \mathrm{kg}$ and $4.02-4.70$ $\mathrm{mg} / \mathrm{kg}$ respectively) were observed among the other treatments. However, a difference was observed in the forms of $\mathrm{N}$ present. The proportion of $\mathrm{N}-\mathrm{NH}_{4}{ }^{+}$was greater than the $\mathrm{N}-\mathrm{NO}_{3}{ }^{-}$only in the digestate treatment. Digestate has a large proportion of organically bound $\mathrm{N}(50-75 \%)$ which is available only after mineralisation [27]. The results suggest that, due to the short duration of the experiments, only a minor amount of this total $\mathrm{N}$ was nitrified. For the plants to utilise more $\mathrm{N}$ from the digestate, a longer period of crop growth and $\mathrm{N}$ uptake would be necessary. 
Table 6. Content of mineral nitrogen $\left(\mathrm{N}_{\min }\right)$ in the soil after harvest (2010 and 2011)

\begin{tabular}{ccccc}
\hline Treatment & Description & \multicolumn{3}{c}{$\mathrm{mg} / \mathrm{kg} \mathrm{DM}$} \\
\cline { 3 - 5 } No. & & ${\mathrm{N}-\mathrm{NH}_{4}{ }^{+}}^{-}{\mathrm{N}-\mathrm{NO}_{3}{ }^{-}}$ & $\mathrm{N}_{\min }$ \\
\hline & & & Year 2010 & \\
2 & Control & 1.56 & 1.71 & $3.27^{\mathrm{a}}$ \\
3 & N fertiliser & 2.45 & 5.12 & $7.57^{\mathrm{b}}$ \\
4 & Digestate & 3.80 & 2.32 & $6.12^{\mathrm{b}}$ \\
& NPKMg fertiliser & 3.08 & 4.10 & $7.18^{\mathrm{b}}$ \\
1 & & & Year 2011 & \\
2 & Control & 1.11 & 1.30 & $2.41^{\mathrm{a}}$ \\
3 & N fertiliser & 1.73 & 2.29 & $4.02^{\mathrm{b}}$ \\
4 & Digestate & 2.73 & 1.97 & $4.70^{\mathrm{b}}$ \\
\hline
\end{tabular}

DM - dry matter; Different letters $(a, b)$ within the columns indicate significant differences between treatments for each year extra $(\mathrm{P}<0.05)$

\section{Weight of single bulbs}

One characteristic of kohlrabi is a high demand for $\mathrm{N}$ from the soil [28], and therefore deficiency of $\mathrm{NO}_{3}-\mathrm{N}$ in the soil reduces yields [29]. Sharof and Weir [30] studied the minimum amount of $\mathrm{N}$ required by vegetable crops, including kohlrabi, in relation to $\mathrm{N}$ balance in the soil and found that $\mathrm{N}$ requirements were invariably lower than values indicated by field trials.

As early as the first stages of growth in this pot study, there was a visible difference between the fertilised treatments and the unfertilised control. The plants in the latter had a lighter colour and growth of the above-ground biomass was markedly slower. At harvest, symptoms of P deficiency (violet discolouration) were detected on bulbs of the control treatment, which was the result of low $\mathrm{P}$ supply to the soil and relatively unsuitable $\mathrm{pH}$ value for $\mathrm{P}$ uptake.

The weight of the unfertilised bulbs was $48.5 \%$ (2010) and 66.2\% (2011) lower than those in the treatment with $\mathrm{N}$ fertiliser only (Table 7). This demonstrates that $\mathrm{N}$ is an important element in terms of yield [31, 28]. However the weight of single bulbs fertilised with the digestate and with NPKMg fertilisers was significantly higher, by $34.7-42.9 \%$ (digestate) and 37.2-38.2\% (NPKMg fertilisers) respectively, than that of bulbs fertilised with $\mathrm{N}$ fertiliser only. The positive synergistic effect of additional nutrients (especially $\mathrm{P}, \mathrm{K}, \mathrm{Mg}$ ) on yield formation was apparent for the digestate and NPKMg fertiliser treatments. However, no significant differences were found between these two treatments. Lošák et al. [39] found the same yield results with kohlrabi of a different variety (Segura F1).

Table 7. Weight of single bulb for each of the treatments (2010 and 2011)

\begin{tabular}{cccccc}
\hline \multirow{2}{*}{$\begin{array}{c}\text { Treatment } \\
\text { No. }\end{array}$} & \multirow{2}{*}{ Description } & \multicolumn{4}{c}{ Weight of one bulb } \\
\cline { 3 - 6 } & & $\mathrm{g}$ & rel. \% & $\mathrm{g}$ & Year 2010 \\
\cline { 3 - 6 } & Control & $66^{\mathrm{a}}$ & 51.5 & $40^{\mathrm{a}}$ & 33.8 \\
\hline 1 & N fertiliser & $128^{\mathrm{b}}$ & 100.0 & $118^{\mathrm{b}}$ & 100.0 \\
2 & Digestate & $183^{\mathrm{c}}$ & 142.9 & $159^{\mathrm{c}}$ & 134.7 \\
3 & NPKMg fertiliser & $177^{\mathrm{c}}$ & 138.2 & $162^{\mathrm{c}}$ & 137.2 \\
\hline
\end{tabular}

Different letters $(a, b, c)$ within the columns indicate significant differences between treatments for each year extra $(\mathrm{P}<0.05)$ 
In experiments lasting several years, Stinner et al. [3] also reported positive effects of three different types of digestate (fermented clover-grass mixture, cover crops and post-harvest residues) on wheat yields. Similarly, Bath and Elfstrand [7] reported that yields of leek were higher after digestate application than after fertilisation with compost. On soil with a low or satisfactory supply of available nutrients, Cigánek et al. [1] found that grain yield of winter wheat increased by 30.0-63.9\% and seed yield of winter rape by $38.5-57.7 \%$ when fertilised with digestate compared with an unfertilised control.

\section{Content of ascorbic acid and nitrates in bulbs}

Vitamin C, including ascorbic acid and dehydroascorbic acid, is one of the important nutritional quality factors in many horticultural crops and has many biological functions in the human body. The content of vitamin $C$ in vegetables can be influenced by various factors such as genotype differences, pre-harvest climatic conditions and cultural practices, maturity and harvesting method, and post-harvest handling procedures [32]. Mozafar [33] reported that $\mathrm{N}$ fertilisers, especially at high rates, seem to decrease the concentration of vitamin $\mathrm{C}$ in many different vegetables. In contrast, Nilsson [34] reported that $\mathrm{N}$ fertilisation did not affect the content of vitamin $\mathrm{C}$ in cauliflower.

The lowest content of ascorbic acid in kohlrabi in this study was observed in the unfertilised control (Table 8). A number of authors have concluded that adequate nutrition and fertilisation helps to increase yields and quality parameters, e.g. vitamin content [31, 23]. Maurya et al. [35] showed that with higher $\mathrm{N}$ doses cauliflower contained significantly more vitamin C. No significant differences in the ascorbic acid content were detected between the fertilised treatments (Table 8).

The concentration of $\mathrm{NO}_{3}{ }^{-}$in plants is affected primarily by the vegetable species, level of $\mathrm{N}$ fertilisation, plant organ analysed, growth stage and the sulphur concentration in the tissues $[36,37]$. Kohlrabi is prone to a higher risk of nitrate accumulation in tissues than some other vegetables [31]. The lowest nitrate content was observed in the unfertilised treatment and the second lowest nitrate content in the digestate treatment (Table 8). The same results were described by Lošák et al. [39] with kohlrabi variety Segura F1. The reason is probably that the digestate contains a significant proportion of organic $\mathrm{N}(25-50 \%)$, which is subject to mineralisation and subsequent nitrification only after a certain period [27].

Table 8. Content of ascorbic acid and nitrates in kohlrabi bulbs grown in the different treatments

\begin{tabular}{cccccc}
\hline \multirow{2}{*}{$\begin{array}{c}\text { Treatment } \\
\text { No. }\end{array}$} & Description & \multicolumn{2}{c}{$\begin{array}{c}\text { Content of ascorbic acid } \\
(\mathrm{mg} / \mathrm{kg} \mathrm{FM})\end{array}$} & \multicolumn{2}{c}{$\begin{array}{c}\text { Nitrate content } \\
(\mathrm{mg} / \mathrm{kg} \mathrm{FM})\end{array}$} \\
\cline { 2 - 5 } & & Year 2010 & Year 2011 & Year 2010 & Year 2011 \\
\hline 1 & Control & $552^{\mathrm{a}}$ & $311^{\mathrm{a}}$ & $36^{\mathrm{a}}$ & $58^{\mathrm{a}}$ \\
2 & N fertiliser & $763^{\mathrm{b}}$ & $354^{\mathrm{b}}$ & $798^{\mathrm{c}}$ & $695^{\mathrm{c}}$ \\
3 & Digestate & $774^{\mathrm{b}}$ & $364^{\mathrm{b}}$ & $197^{\mathrm{b}}$ & $230^{\mathrm{b}}$ \\
4 & NPKMg fertiliser & $768^{\mathrm{b}}$ & $352^{\mathrm{b}}$ & $785^{\mathrm{c}}$ & $699^{\mathrm{c}}$ \\
\hline
\end{tabular}

FM - fresh matter; Different letters $(a, b, c)$ within the columns indicate significant differences between treatments for each year extra $(\mathrm{P}<0.05)$

It can be assumed that during the short growing period of kohlrabi (approx. 7 weeks), only part of the organically bound nitrogen was mineralised. Therefore mineral $\mathrm{N}^{-} \mathrm{NH}_{4}{ }^{+}$ from the digestate (or after its nitrification $\mathrm{N}-\mathrm{NO}_{3}{ }^{-}$) was available to the plants and was sufficient for yield formation, but did not increase the nitrate content in the bulbs. The nitrate content was highest in the two treatments fertilised with nitrogen in the form of 
urea ( $\mathrm{N}$ and NPKMg fertiliser treatments), where it was threefold that in the digestate treatment (Table 8).

\section{Macronutrients content of the bulbs}

In terms of the content of macronutrients in the bulbs (Table 9), the differences were most marked in the case of nitrogen. The $\mathrm{N}$ content was highest in the urea-fertilised treatments ( $\mathrm{N}$ and NPKMg fertiliser treatments) from which the plants could exploit the available forms, i.e. $\mathrm{NH}_{4}{ }^{+}$and $\mathrm{NO}_{3}{ }^{-}$.

In the digestate treatment, the $\mathrm{N}$ content in kohlrabi tissues was significantly lower as a result of limited mineralisation of organically bound $\mathrm{N}$ within the short time interval. Furthermore the addition of readily degradable $\mathrm{C}$ compounds may have led to immobilisation of mineral $\mathrm{N}$ in soil [26]. In terms of the other nutrients, there were mostly no significant differences between the treatments.

Table 9. Contents of macronutrients in the bulbs grown using the different treatments

\begin{tabular}{ccccccc}
\hline Treat. & \multirow{2}{*}{ Description } & \multicolumn{5}{c}{$\%$ in DM } \\
\cline { 3 - 6 } No. & & $\mathrm{N}$ & $\mathrm{P}$ & $\mathrm{K}$ & $\mathrm{Ca}$ & $\mathrm{Mg}$ \\
\hline & & & & Year 2010 \\
1 & Control & $1.16^{\mathrm{a}}$ & $0.28^{\mathrm{b}}$ & $2.68^{\mathrm{a}}$ & $0.25^{\mathrm{a}}$ & $0.12^{\mathrm{a}}$ \\
2 & N fertiliser & $2.72^{\mathrm{c}}$ & $0.20^{\mathrm{a}}$ & $2.72^{\mathrm{a}}$ & $0.24^{\mathrm{a}}$ & $0.13^{\mathrm{a}}$ \\
3 & Digestate & $1.61^{\mathrm{b}}$ & $0.27^{\mathrm{b}}$ & $2.72^{\mathrm{a}}$ & $0.25^{\mathrm{a}}$ & $0.11^{\mathrm{a}}$ \\
4 & NPKMg fertiliser & $2.23^{\mathrm{c}}$ & $0.28^{\mathrm{b}}$ & $2.80^{\mathrm{a}}$ & $0.27^{\mathrm{a}}$ & $0.12^{\mathrm{a}}$ \\
& & & & Year 2011 & & \\
1 & Control & $1.32^{\mathrm{a}}$ & $0.25^{\mathrm{ab}}$ & $3.01^{\mathrm{a}}$ & $0.21^{\mathrm{a}}$ & $0.14^{\mathrm{a}}$ \\
2 & N fertiliser & $2.55^{\mathrm{c}}$ & $0.22^{\mathrm{a}}$ & $2.99^{\mathrm{a}}$ & $0.23^{\mathrm{b}}$ & $0.13^{\mathrm{a}}$ \\
3 & Digestate & $2.16^{\mathrm{b}}$ & $0.29^{\mathrm{c}}$ & $3.11^{\mathrm{a}}$ & $0.23^{\mathrm{b}}$ & $0.13^{\mathrm{a}}$ \\
4 & NPKMg fertiliser & $2.67^{\mathrm{c}}$ & $0.28^{\mathrm{bc}}$ & $3.21^{\mathrm{a}}$ & $0.24^{\mathrm{b}}$ & $0.15^{\mathrm{a}}$ \\
\hline
\end{tabular}

$\mathrm{DM}$ - dry matter; Different letters $(\mathrm{a}, \mathrm{b}, \mathrm{c})$ within the columns indicate significant differences between treatments for each year extra $(\mathrm{P}<0.05)$

A low $\mathrm{P}$ content was detected in the tissues of plants where urea alone was applied (treatment 2), which was due to its low content in the soil and alkaline $\mathrm{pH}$ negatively affecting its uptake [23]. Möller and Stinner [38] reported that slurry digestion did not influence plant $\mathrm{P}$ and $\mathrm{K}$ uptake.

\section{CONCLUSIONS}

Digestate application resulted in comparable or better soil chemical properties, crop yield and quality parameters of kohlrabi than mineral fertiliser application. When available, the application of digestate can potentially offer considerable savings compared with the purchase of mineral fertilisers. However, digestates are poor in labile organic substances and the soil must be supplied with these from other sources, if required.

\section{ACKNOWLEDGEMENT}

This study was supported by the Internal Grant Agency of the Faculty of Agronomy of Mendel University in Brno No. TP 5/2010, TP 9/2011 and TP 11/2013. We thank to Mr. Chris Dawson from the UK for the language revision. 


\section{REFERENCES}

1. Cigánek, K., Lošák, T., Szostková, M., Zatloukalová, A., Pavlíková, D., Vítěz, T., Fryč, J., Dostál, J., Verification of the Effectiveness of Fertilisation with Digestates from Biogas Stations on Yields of Winter Rape and Winter Wheat and changes in some Agrochemical Soil Properties, Agrochemistry, Vol. 50, No. 3, pp 16-21, 2010.

2. Möller, K. and Müller, T., Effect of Anaerobic digestion on Digestate Nutrient availability and Crop growth: A Review, Engineering in Life Sciences, Vol. 12, No. 3, pp 242-257, 2012, http://dx.doi.org/10.1002/elsc.201100085

3. Stinner, W., Möller, K. and Leithold, G., Effects of Biogas digestion of Clover/grass-leys, Cover Crops and Crop Residues on Nitrogen Cycle and Crop Yield in Organic stockless Farming Systems, European Journal of Agronomy, Vol. 29, No. 2-3, pp 125-134, 2008, http://dx.doi.org/10.1016/j.eja.2008.04.006

4. Arthurson, V., Closing the Global Energy and Nutrient Cycles through Application of Biogas Residue to Agricultural Land-potential Benefits and Drawbacks, Energies, Vol. 2, No. 2, pp 226-242, 2009, http://dx.doi.org/10.3390/en20200226

5. Gunnarsson, A., Bengtsson, F. and Caspersen, S., Use efficiency of Nitrogen from Biodigested Plant Material by Ryegrass, Journal of Plant Nutrition and Soil Science, Vol. 173, No. 1, pp 113-119, 2010, http://dx.doi.org/10.1002/jpln.200800250

6. Ross, D. J., Tate, K. R., Speir, T. W., Stewart, D. J. and Hewitt, A. E., Influence of Biogas-digester effluent on Crop growth and Soil Biochemical Properties under Rotational cropping, New Zealand Journal of Crop and Horticultural Science, Vol.17, No.1, pp 77-87, 1989, http://dx.doi.org/10.1080/01140671.1989.10428013

7. Bath, B. and Elfstrand, S., Use of Red Clover-based Green Manure in Leek Cultivation, Biological Agriculture \& Horticulture, Vol. 25, No. 3, pp 269-286, 2008, http://dx.doi.org/10.1080/01448765.2008.9755053

8. Odlare, M., Pell, M. and Svensson, K., Changes in Soil Chemical and Microbiological Properties during 4 years of Application of Various Organic Residues, Waste Management, Vol. 28, No. 7, pp 1246-1253, 2008, http://dx.doi.org/10.1016/j.wasman.2007.06.005

9. Kolář, L., Kužel, S., Peterka, J. and Borová-Batt, J., Agrochemical Value of the Liquid Phase of Wastes from Fermenters during Biogas Production, Plant, Soil and Environment, Vol. 56, No. 1, pp 23-27, 2010.

10. Lošák, T., Zatloukalová, A., Szostková, M., Hlušek, J., Fryč, J., Vítěz, T., Comparison of the Effectiveness of Digestate and Mineral Fertilisers on Yields and Quality of Kohlrabi (Brassica oleracea, L.), Acta Universitatis Agriculturae et Silviculturae Mendeleianae Brunensis, Vol. 59, No. 3, pp 117-122, 2011, http://dx.doi.org/10.11118/actaun201159030117

11. Möller, K., Influence of different Manuring Systems with and without Biogas Digestion on Soil Organic Matter and Nitrogen Inputs, Flows and Budget in Organic Cropping Systems, Nutrient Cycling in Agroecosystems, Vol. 84, No. 2, pp 179-202, 2009, http://dx.doi.org/10.1007/s10705-008-9236-5

12. Amon, T. and Döhler, H., Handreichung-Biogasgewinnung und -nutzung, Fachagentur Nachwachsende Rohstoffe e.V. (ed.), KTBL, Darmstadt, 2004.

13. Quakernack, R., Pacholski, A., Techow, A., Herrmann, A., Taube, F. and Kage, H., Ammonia volatilization and Yield response of Energy Crops after fertilization with Biogas Residues in a Coastal marsh of Northern Germany, Agriculture, Ecosystems and Environment, Vol. 160, 2011, http://dx.doi.org/10.1016/j.agee.2011.05.030

14. Gericke, D., Bornemann, L., Kage, H. and Pacholski, A., Modelling Ammonia losses after Field application of Biogas Slurry in Energy Crop Rotations, Water Air and Soil 


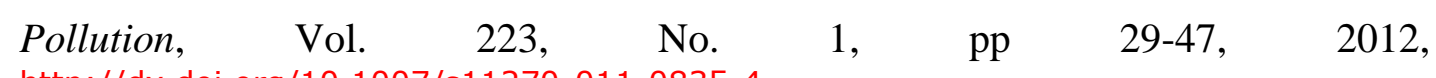
http://dx.doi.org/10.1007/s11270-011-0835-4

15. Alburquerque, J. A., de la Fuente, C. and Bernal, M. P., Chemical properties of Anaerobic Digestates affecting $\mathrm{C}$ and N dynamics in Amended Soils, Agriculture, Ecosystems and Environment, Vol. 160, 2011, http://dx.doi.org/10.1016/j.agee.2011.03.007

16. Möller, K., Schulz, R. and Müller, T., Effects of setup of Centralized Biogas Plants on Crop Acreage and Balances of Nutrients and Soil Humus, Nutrient Cycling in Agroecosystems, Vol. 89, No. 1, pp 303-312, 2011, http://dx.doi.org/10.1007/s10705-010-9395-z

17. Zbíral, J., Soil Analysis I, Integrated Work Procedures, ÚKZÚZ, Brno, 2002.

18. Zbíral, J., Plant Analysis, Integrated Work Procedures, ÚKZÚZ, Brno, 1994.

19. Plaixats, J., Barcelo, J. and Garcia-Moreno, J., Characterization of the Effluent Residue from Anaerobic digestion of Pig Excreta for its Utilization as Fertilizer, Agrochemica, Vol. 32, No. 2-3, pp 236-239, 1988.

20. Gerardi, M. H., The Microbiology of Anaerobic Digesters, John Wiley and Sons, Inc: Hoboken, NJ, U.S.A., 2003, http://dx.doi.org/10.1002/0471468967

21. Loria, E. R. and Sawyer, J. E., Extractable Soil Phosphorus and Inorganic Nitrogen following Application of Raw and Anaerobically digested Swine Manure, Agronomy Journal, Vol. 97, No. 3, pp 879-885, 2005, http://dx.doi.org/10.2134/agronj2004.0249

22. Fuchs, J. G., Berner, A., Mayer, J. and Schleiss, K., Influence of Composts and Digestats on Soil Fertility, Agrarforschung, Vol. 15, No. 6, pp 276-281, 2008.

23. Mengel, K. and Kirkby, E. A., Principles of Plant Nutrition, $5^{\text {th }}$ edition, Kluwer Academic Publishers, Dordrecht/Boston/London, 2001, http://dx.doi.org/10.1007/978-94-010-1009-2

24. Möller, K. and Stinner, W., Influence of different Manuring Systems with and without Biogas digestion on Soil Mineral Nitrogen Content and on Gaseous Nitrogen losses (ammonia, nitrous oxides), European Journal of Agronomy, Vol. 30, No. 1, pp 1-16, 2009, http://dx.doi.org/10.1016/j.eja.2008.06.003

25. Pang, X. P. and Letey, J., Organic farming: Challenge of timing Nitrogen availability to crop Nitrogen Requirements, Soil Science Society of America Journal, Vol. 64, No. 1, pp 247-253, 2000, http://dx.doi.org/10.2136/sssaj2000.641247x

26. Dosch, $\mathrm{P}$. and Gutser, R., Reducing $\mathrm{N}$ losses $\left(\mathrm{NH}_{3}, \mathrm{~N}_{2} \mathrm{O}, \mathrm{N}_{2}\right)$ and Immobilization from Slurry through Optimized Application Techniques, Fertilizer Research, Vol. 43, No. 1-3, pp 165-171, 1996, http://dx.doi.org/10.1007/BF00747697

27. Kirchmann, H. and Witter, E., Composition of Fresh Aerobic and Anaerobic Farm Animal Dungs, Bioresource Technology, Vol. 40, No. 2, pp 137-142, 1992, http://dx.doi.org/10.1016/0960-8524(92)90199-8

28. Feller, C. and Fink, M., Nitrogen uptake of Kohlrabi, estimated by Growth Stages and an Empirical Growth Model, Journal of Plant Nutrition and Soil Science, Vol. 160, No. 6, pp 589-594, 1997.

29. Steingrobe, G. and Schenk, M. K., Influence of Nitrate Concentration at the Root Surface on Yield and Nitrate uptake of Kohlrabi (Brassica oleracea-gongyloides, L.) and Spinach (Spinacia oleracea, L.), Plant and Soil, Vol. 135, No. 2, pp 205-211, 1991, http://dx.doi.org/10.1007/BF00010908

30. Sharof, H. C. and Weir, U., Calculation of nitrogen immobilization and fixation, Gartenbau Hannover Germany, Bodenkunde, 1994.

31. Hlušek, J., Richter, R. and Ryant, P., Výživa a hnojení zahradnich plodin, 1th ed., Zemědělec, Praha, 2002. (in czech) 
32. Lee, S. K. and Kader, A. A., Preharvest and Postharvest Factors influencing Vitamin C Content of Horticultural Crops, Postharvest Biology and Technology, Vol. 20, No. 3, pp 207-220, 2000, http://dx.doi.org/10.1016/S0925-5214(00)00133-2

33. Mozafar, A., Nitrogen Fertilizers and the amount of Vitamins in Plants: A Review, Journal of Plant Nutrition, Vol. 16, No. 12, pp 2479-2506, 1993, http://dx.doi.org/10.1080/01904169309364698

34. Nilsson, T., The influence of Soil Type, Nitrogen and Irrigation on Yield, Quality and Chemical Composition of Cauliflower, Swedish Journal of Agricultural Research, Vol. 10, No. 2, pp 65-75, 1980.

35. Maurya, A. N., Chaurasia, S. N. S. and Reddy, Y. R. M., Effect of Nitrogen and Molybdenum Levels on Growth, Yield and Quality of Cauliflower (Brassica oleracea var. Botrytis) cv. Snowball-16, Haryana Journal of Horticultural Sciences, Vol. 21, No. 3-4, pp 232-235, 1992.

36. Lošák, T., Hlušek, J., Kráčmar, S. and Varga, L., The effect of Nitrogen and Sulphur Fertilization on Yield and Quality of Kohlrabi (Brassica oleracea, L.), Revista Brasileira de Ciencia do Solo, Vol. 32, No. 2, pp 697-703, 2008, http://dx.doi.org/10.1590/S0100-06832008000200024

37. Marschner, H., Mineral Nutrition of Higher Plants, 2nd edition, Academic Press, London, 2002.

38. Möller, K. and Stinner, W., Effect of Organic Wastes digestion for Biogas production on Mineral Nutrient availability of Biogas Effluents, Nutrient Cycling in Agroecosystems, Vol. 87, No. 3, pp 395-413, 2010, http://dx.doi.org/10.1007/s10705-010-9346-8

39. Lošák, T., Musilová, L., Zatloukalová, A., Szostková, M., Hlušek, J., Fryč, J., Vítěz, T., Haitl, M., Bennewitz, E. and Martensson, A., Digestate is Equal or a Better Alternative to Mineral Fertilization of Kohlrabi, Acta Universitatis Agriculturae et Silviculturae Mendeleianae Brunensis, Vol. 60, No. 1, pp 91-96, 2012, http://dx.doi.org/10.11118/actaun201260010091 